\title{
Good outcomes of pregnancy in two cases of women treated with omalizumab due to the severe asthma
}

\author{
Izabela Kuprys-Lipinska*, Piotr Kuna \\ From EAACI International Severe Asthma Forum (ISAF 2012) \\ Gothenburg, Sweden. 11-13 October 2012
}

The prevalence of asthma during pregnancy is estimated on $4 \%$. Uncontrolled, severe asthma is a risk for both a mother and an unborn child. Therefore, optimization of asthma treatment during pregnancy is vital in achieving good outcomes. Physicians and their patients may have some doubts about safety of anti-asthmatic medications, especially if drugs are new. Omalizumab is a humanized recombinant anti-IgE monoclonal antibody recommended for the treatment of chronic severe IgE-mediated asthma. Clinical and observational studies confirmed its effectiveness in improving asthma control, reducing severe exacerbations and improving quality of life. The safety data concerning pregnancy come from the experimental studies on animals and they show no teratogenic effect. We present case reports of two women who became pregnant during the treatment with omalizumab. Both with very severe asthma treated chronically with all available medication including systemic steroids (first - $20 \mathrm{mg}$ prednisolone/day, second - $40 \mathrm{mg}$ prednisolone/day). Both started their regular treatment with omalizumab in 2007 and have significant improvement (withdrawal of oral steroids or significant reduction of their dose, better asthma control) . First, 32-year old woman became pregnant in 2010 and gave birth in Oct 2010 - it was her 3rd pregnancy, and 3rd labor, second 31-year old - also became pregnant in 2010 and gave birth in Jan 2011 - it was her 5th pregnancy and 2nd labor. Both had complications during previous pregnancies and labors and decided to continue therapy with omalizumab. First woman, besides omalizumab, was treated with high doses of ICS and LABA, second - high doses of ICS, LABA and $5 \mathrm{mg}$ prednisone/day. The pregnancies proceeded without asthma exacerbations and other

Medical University of Lodz, Dept of Internal Medicine, Asthma and Allergy, Poland

() Biomed Central

(c) 2013 Kuprys-Lipinska and Kuna; licensee BioMed Central Ltd. This is an Open Access article distributed under the terms of the Creative Commons Attribution License (http://creativecommons.org/licenses/by/2.0), which permits unrestricted use, distribution, and complications. First woman delivered healthy girl (Apgar 9, weight $3200 \mathrm{~g}$, length $56 \mathrm{~cm}$ ) in 40 week of pregnancy by caesarean section due to the narrow pelvis, second health boy (Apgar 9, weight $3800 \mathrm{~g}$, length $56 \mathrm{~cm}$ ) in 40 week by caesarean section due to the aggravating obstetrical history. In both cases treatment with omalizumab did not affect pregnancies and newborns.

Published: 3 May 2013

doi:10.1186/2045-7022-3-S1-P25

Cite this article as: Kuprys-Lipinska and Kuna: Good outcomes of severe asthma. Clinical and Translational Allergy 2013 3(Suppl 1):P25.

Submit your next manuscript to BioMed Central and take full advantage of:

- Convenient online submission

- No space constraints or color figure charges

- Immediate publication on acceptance

- Inclusion in PubMed, CAS, Scopus and Google Scholar

- Research which is freely available for redistribution pregnancy in two cases of women treated with omalizumab due to the

- Thorough peer review

\section{reproduction in any medium, provided the original work is properly cited.}

